\title{
Amphritea japonica sp. nov. and Amphritea balenae sp. nov., isolated from the sediment adjacent to sperm whale carcasses off Kagoshima, Japan
}

\author{
Masayuki Miyazaki, ${ }^{1}$ Yuichi Nogi, ${ }^{1}$ Yoshihiro Fujiwara, ${ }^{1}$ Masaru Kawato, ${ }^{1}$ \\ Takahiko Nagahama, ${ }^{1}$ Kaoru Kubokawa ${ }^{2}$ and Koki Horikoshi ${ }^{1}$ \\ ${ }^{1}$ Extremobiosphere Research Center, Japan Agency for Marine-Earth Science and Technology \\ (JAMSTEC), 2-15 Natsushima-cho, Yokosuka 237-0061, Japan \\ ${ }^{2}$ Center for Advanced Marine Research, Ocean Research Institute, The University of Tokyo, 1-15-1 \\ Minamidai, Nakano-ku, Tokyo 164-8639, Japan
}

Correspondence

Masayuki Miyazaki

miyazakim@jamstec.go.jp

\begin{abstract}
Two novel species were isolated from the sediment adjacent to sperm whale carcasses off Kagoshima, Japan, at a depth of about $230 \mathrm{~m}$. The isolated strains, JAMM $1866^{\top}$, JAMM 1548 and JAMM $1525^{\top}$, were Gram-negative, rod-shaped, non-spore-forming and motile by means of a single polar or bipolar flagellum. Phylogenetic analysis based on 16S rRNA gene sequences of strains JAMM $1866^{\top}$ and JAMM 1548 indicated a relationship to the symbiotic bacterial clone R21 of Osedax japonicus (100\% sequence similarity) and all three isolates were closely related to Amphritea atlantica (97.7-97.8\% similarity) within the class Gammaproteobacteria. The novel isolates were able to produce isoprenoid quinone Q-8 as the major component. The predominant fatty acids were $\mathrm{C}_{16: 0}, \mathrm{C}_{16: 1}$ and $\mathrm{C}_{18: 1}$, with $\mathrm{C}_{12: 1} 3-\mathrm{OH}$ present in smaller amounts. The DNA $\mathrm{G}+\mathrm{C}$ contents of the three isolated strains were about $47 \mathrm{~mol} \%$. Based on differences in taxonomic characteristics, the three isolated strains represent two novel species of the genus Amphritea for which the names Amphritea japonica sp. nov. (type strain JAMM $1866^{\top}=\mathrm{JCM}$

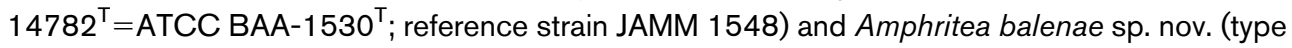
strain JAMM $1525^{\top}=$ JCM $14781^{\top}=$ ATCC BAA-1529 ${ }^{\top}$ ) are proposed.
\end{abstract}

Members of the genus Amphritea are described as Gramnegative, rod-shaped cells with a monopolar flagellum and have been isolated from a Bathymodiolus sp. specimen collected at the Mid-Atlantic Ridge at a depth of about $3000 \mathrm{~m}$ (Gärtner et al., 2008). Amphritea atlantica is the only recognized species of this genus. The genus Amphritea is related to the genera Oceanospirillum and Neptunomonas and to a symbiotic bacterial clone of Osedax (Goffredi et al., 2007). The genus Osedax (Polychaeta: Siboglinidae) has recently been discovered in whale carcass environments on the deep-sea floor (Rouse et al., 2004; Glover et al., 2005; Fujikura et al., 2006; Braby et al., 2007). Osedax specimens host symbiotic bacteria in their ovisac and root systems. Phylogenetic analysis placed these Osedax microbes within a well-supported clade of the Gammaproteobacteria that contains heterotrophic members of the order

Abbreviations: ML, maximum likelihood; NJ, neighbour-joining.

The GenBank/EMBL/DDBJ accession numbers for the 165 rRNA gene sequences of strains JAMM $1866^{\top}$, JAMM 1548 and JAMM $1525^{\top}$ are AB330881-AB330883, respectively.

Transmission electron micrographs of negatively stained cells of the two novel species described in this study are available with the online version of this paper.
Oceanospirillales (Goffredi et al., 2007). Most genera of the order Oceanospirillales (Garrity et al., 2005) are halotolerant or halophilic and motile. These genera are aerobic, microaerophilic or facultatively anaerobic chemoorganotrophs. Sperm whale carcass ecosystems off Kagoshima, Japan, were investigated over a period of 3 years (Fujiwara et al., 2007). About 800 aerobic bacteria were isolated from sediment adjacent to the sperm whale carcasses and three of these strains were related to members of the family Oceanospirillaceae and a symbiotic bacterial clone of Osedax japonicus. In this paper, several lines of evidence are presented that indicate that these isolates represent two novel species of the genus Amphritea.

The three strains, JAMM $1866^{\mathrm{T}}$, JAMM 1548 and JAMM $1525^{\mathrm{T}}$, were collected from marine sediment adjacent to the sperm whale carcasses by the unmanned ROV Hyper Dolphin off Kagoshima, Japan (dive 457, $31^{\circ} 20.720^{\prime} \mathrm{N}$ $129^{\circ} 59.285^{\prime} \mathrm{E}$, at a depth of $228 \mathrm{~m}$; dive 465, $31^{\circ} 20.730^{\prime} \mathrm{N} 129^{\circ} 59.314^{\prime} \mathrm{E}$, at a depth of $229 \mathrm{~m}$ ) during cruise NT05-12. The sediment samples were collected with the manipulator of the ROV and placed in the sample holder of the sterilized sampler. A portion of each sample was cultivated on marine agar 2216 (MA; Difco) at $12{ }^{\circ} \mathrm{C}$ 
for approximately 7 days. The bacteria were maintained on MA plates or in marine broth 2216 (MB; Difco) at $20{ }^{\circ} \mathrm{C}$ and stored at $-80{ }^{\circ} \mathrm{C}$ in $15 \%(\mathrm{v} / \mathrm{v})$ glycerol. Unless otherwise indicated, physiological tests were performed according to the general procedures described by Barrow \& Feltham (1993) and Miyazaki et al. (2008b) with the modification that artificial seawater (ASW; $1 \times$ ASW consisting of $2.75 \% \quad \mathrm{NaCl}, \quad 0.07 \% \quad \mathrm{KCl}, \quad 0.54 \%$ $\mathrm{MgCl}_{2} .6 \mathrm{H}_{2} \mathrm{O}, \quad 0.68 \% \quad \mathrm{MgSO}_{4} .7 \mathrm{H}_{2} \mathrm{O}, \quad 0.14 \%$ $\left.\mathrm{CaCl}_{2}, 2 \mathrm{H}_{2} \mathrm{O}, 0.02 \% \mathrm{NaHCO}_{3}\right)$ was used. Growth at various temperatures $\left(4-30{ }^{\circ} \mathrm{C}\right)$ was measured in $\mathrm{MB}$ for 7 days. Growth at various $\mathrm{NaCl}$ concentrations was examined in medium containing $0.5 \%$ peptone (Difco), $0.5 \%$ yeast extract (Difco) and $0.32 \% \mathrm{MgSO}_{4} .7 \mathrm{H}_{2} \mathrm{O}$, with $\mathrm{NaCl}$ concentrations of $0-6 \%(\mathrm{w} / \mathrm{v})$ ( $\mathrm{pH}$ adjusted to 7.2 at $20{ }^{\circ} \mathrm{C}$ ). The $\mathrm{pH}$ range for growth was determined in $0.5 \%$ peptone, $0.5 \%$ yeast extract, $0.32 \% \mathrm{MgSO}_{4} \cdot 7 \mathrm{H}_{2} \mathrm{O}$ and $3.0 \% \mathrm{NaCl}(\mathrm{w} / \mathrm{v})$, with the $\mathrm{pH}$ adjusted to $6.0,6.5,7.0,7.5$, 8.0 and 8.5. The test strains retained viability for about 7 days at the optimal temperature. Acid production from sugars was assessed using modified oxidization-fermentation medium (Hugh \& Leifson, 1953) containing $0.5 \times$ ASW, $0.1 \%\left(\mathrm{NH}_{4}\right)_{2} \mathrm{SO}_{4}, 0.1 \%$ yeast extract (Difco), $0.1 \%$ Tris, $1.4 \% \mathrm{NaCl}, 1 \%$ sugar and $0.006 \%$ bromothymol blue ( $\mathrm{pH}$ adjusted to 7.2 at $20{ }^{\circ} \mathrm{C}$ ) and incubated at the optimum temperature. Oxidase activity was determined by spreading cell pellets on oxidase test paper (Nissui Pharmaceutical). Catalase activity was determined based on bubble production in $3 \%(\mathrm{v} / \mathrm{v}) \mathrm{H}_{2} \mathrm{O}_{2}$ solution. Gelatinase, protease, amylase and lipase (hydrolysis of tri$n$-butyrin) activities were detected on MA plates using substrate concentrations of $1 \%(\mathrm{w} / \mathrm{v})$. DNase activity was assessed using DNase test agar (Difco). Hydrogen sulfide production from thiosulfate and indole production were assessed using SIM medium (Nissui Pharmaceutical) stabs prepared with $0.5 \times$ ASW instead of water. Additional phenotypic characteristics were determined using the Biolog GN2 microbial identification system following the protocol provided by the manufacturer. Susceptibility to antimicrobial substances was examined on MA using Sensi-Discs (Becton Dickinson). Any sign of growth inhibition after $72 \mathrm{~h}$ incubation at $20{ }^{\circ} \mathrm{C}$ was recorded as sensitivity to the respective antimicrobial agent. The following antibiotics (Becton Dickinson) were examined (amounts per disc): ampicillin $(10 \mu \mathrm{g})$, chloramphenicol $(30 \mu \mathrm{g})$, erythromycin $(15 \mu \mathrm{g})$, gentamicin $(10 \mu \mathrm{g})$, kanamycin $(30 \mu \mathrm{g})$, nalidixic acid $(30 \mu \mathrm{g})$, neomycin $(30 \mu \mathrm{g})$, novobiocin $(30 \mu \mathrm{g})$, penicillin (10 IU), streptomycin $(10 \mu \mathrm{g})$ and tetracycline $(30 \mu \mathrm{g})$.

Transmission electron microscopy of negatively stained cells was conducted as described by Nogi et al. (1998). Cells of strains JAMM $1866^{\mathrm{T}}$ and JAMM $1525^{\mathrm{T}}$ grown on MA at optimal temperature and in the mid-exponential phase of growth were used for electron microscopic observations (JEM-1210; JEOL).

Cellular fatty acids and isoprenoid quinones were analysed. Isolated strains were cultured in $\mathrm{MB}$ at optimal growth temperatures. Cellular fatty acids were analysed by GLCMS (Miyazaki et al., 2006). Isoprenoid quinones were extracted with chloroform/methanol (2:1) from dried cells (200 mg) and purified by TLC. The purified isoprenoid quinones were analysed using reversed-phase HPLC (Komagata \& Suzuki, 1987).

Chromosomal DNA was purified using the phenol extraction method (Saito \& Miura, 1963). The DNA $\mathrm{G}+\mathrm{C}$ content was determined using reversed-phase HPLC (Tamaoka \& Komagata, 1984). For analysis of relatedness, DNA-DNA hybridization was carried out at $44{ }^{\circ} \mathrm{C}$ for $4 \mathrm{~h}$ and measured fluorometrically using the method of Ezaki et al. (1989).

16S rRNA gene sequences were obtained by direct sequencing of PCR-amplified DNA as described previously (Miyazaki et al., 2008a). Sequences were aligned with the subset of 16S rRNA gene sequences obtained from GenBank using the FASTALIGNER utility of the ARB software (Ludwig et al., 2004). The phylogenetic relationships of each taxon were inferred with the neighbour-joining (NJ) and maximum-likelihood (ML) methods using PAUP* 4.0 beta 10 (Swofford, 1998). ML trees (Felsenstein, 1981) were inferred using the default starting parameters (NJ using a Jukes-Cantor model of evolution). NJ trees (Saitou \& Nei, 1987) were inferred using the Hasegawa, Kishino and Yano (HGK85) distance. Statistical support of the branch points was tested by performing $1000 \mathrm{NJ}$ and $500 \mathrm{ML}$ bootstrap replications. The GenBank/DDBJ/EMBL accession numbers for the 16S rRNA gene sequences of the isolates are shown in Fig. 1. Other reference sequences were obtained from GenBank.

Cultural, physiological and biochemical characteristics of the isolates are shown in Table 1 and given in the species descriptions below. Physiological and biochemical characteristics of the two groups showed some differences when compared with the type strains of related species and with each other. Strains JAMM $1866^{\mathrm{T}}$ and JAMM 1548 showed no growth at $30{ }^{\circ} \mathrm{C}$ or in $6 \% \mathrm{NaCl}$ and did not hydrolyse Tweens 40 and 80; their DNA G $+\mathrm{C}$ contents differed from those of related strains. Strain JAMM $1525^{\mathrm{T}}$ had a bipolar or polar flagellum, did not grow at $30{ }^{\circ} \mathrm{C}$ or in $6 \% \mathrm{NaCl}$, was positive for catalase (weak) and gelatinase, and did not hydrolyse Tweens 40 and 80; the DNA G+C content differed from those of related strains.

The whole-cell fatty acid compositions of the isolates and reference strains are shown in Table 2 . The major fatty acids of the novel isolates and A. atlantica $\mathrm{M}_{4} 1^{\mathrm{T}}$ were $\mathrm{C}_{16: 0}, \mathrm{C}_{16: 1}$ and $\mathrm{C}_{18: 1}$. Furthermore, these strains contained $\mathrm{C}_{12: 1} 3$ $\mathrm{OH}$, a characteristic feature of the genus Amphritea. The fatty acid profile showed low levels of similarity to those of reference strains. For example, the isolates produced $\mathrm{C}_{12: 1}$ and $\mathrm{C}_{18: 2}$, but $A$. atlantica $\mathrm{M} 41^{\mathrm{T}}$ did not produce $\mathrm{C}_{12: 1}$ and the reference strains did not produce $\mathrm{C}_{18: 2}$.

Results of the NJ phylogenetic analyses using 16S rRNA gene sequences are shown in Fig. 1. These results support 


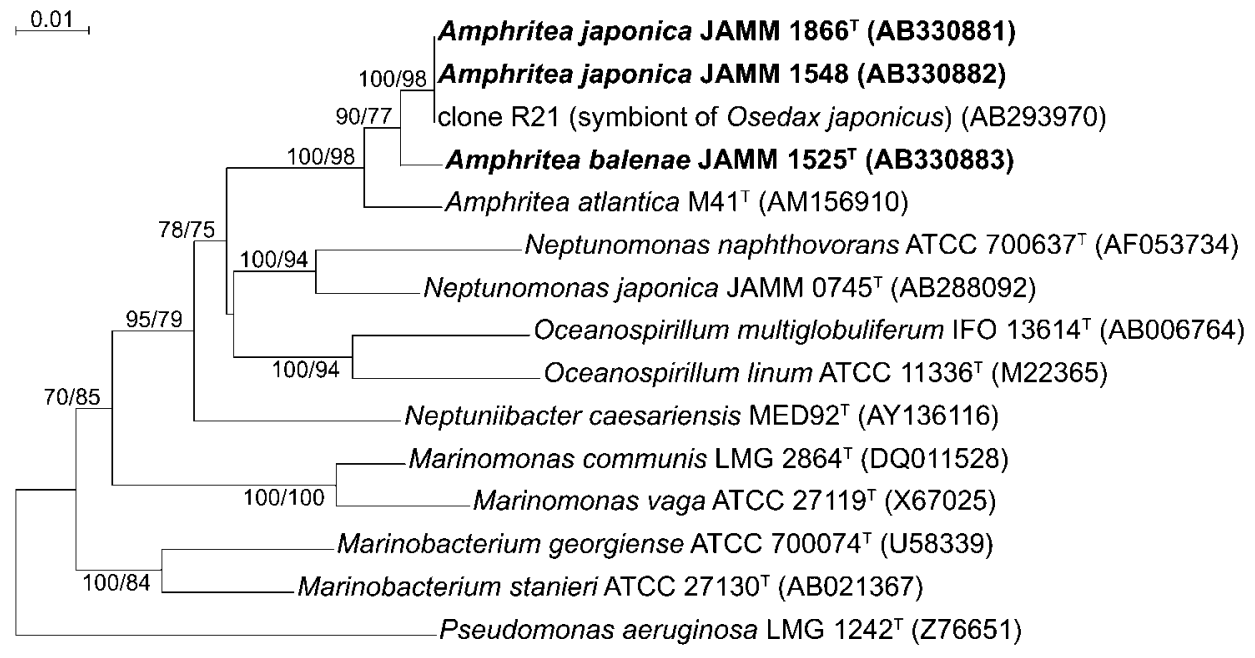

Fig. 1. Phylogenetic tree constructed using the NJ method and based on $16 \mathrm{~S}$ rRNA gene sequences showing the relationship between the three isolates and related members of the class Gammaproteobacteria. The bootstrap resampling percentages (NJ, 1000 replicates; ML, 500 replicates) that support branching points above the $50 \%$ confidence level are indicated. Bar, 0.01 nucleotide substitutions per site.

the conclusions described below and further clarify the taxonomic and phylogenetic positions of the three isolated strains and the symbiotic bacterial clone R21 of Osedax within the genus Amphritea. The three strains showed high sequence similarities to the following species/genera: $A$. atlantica $\mathrm{M} 41^{\mathrm{T}}$ (97.7-97.8\%), genus Neptunomonas (92.6$94.3 \%)$, genus Oceanospirillum (91.3-93.2\%) and Neptuniibacter caesariensis MED92 ${ }^{\mathrm{T}} \quad$ (94.3-94.5\%).
However, they were more closely related to the $16 \mathrm{~S}$ rRNA gene sequence of symbiotic bacterial clone R21 of Osedax japonicus (99.0-100 \%). The level of $16 \mathrm{~S}$ rRNA gene sequence similarity between strains JAMM $1866^{\mathrm{T}}$ and JAMM $1525^{\mathrm{T}}$ was $99.0 \%$. The generally recommended and accepted criteria for delineating bacterial species state that strains with $16 \mathrm{~S}$ rRNA gene sequence dissimilarity of greater than $3 \%$ are considered to belong to separate species

Table 1. Differential characteristics of the two novel Amphritea species and related type species of the family Oceanospirillaceae

Strains: 1, A. japonica sp. nov. (strains JAMM $1866^{\mathrm{T}}$ and JAMM 1548); 2, A. balenae sp. nov. (strain JAMM 1525 $5^{\mathrm{T}}$ ); 3, A. atlantica M41 ${ }^{\mathrm{T}}$; 4 , Neptunomonas naphthovorans ATCC $700637^{\mathrm{T}}$; 5, Oceanospirillum linum NBRC $15448^{\mathrm{T}}$. +, Positive; -, negative; w, weak reaction; ND, no data. Data from this study, Garrity et al. (2005), Gärtner et al. (2008), Hedlund et al. (1999), Holt et al. (1994), Krieg (1984) and Satomi et al. (2002).

\begin{tabular}{|c|c|c|c|c|c|}
\hline Characteristic & 1 & 2 & 3 & 4 & 5 \\
\hline \multicolumn{6}{|l|}{ Cell morphology: } \\
\hline Shape & Rods & Rods & Rods & Rods & Spirillum \\
\hline Length $(\mu \mathrm{m})$ & $0.9-1.7$ & $1.3-2.0$ & $0.5-2.0$ & $2.0-3.0$ & $1.8-4.0$ \\
\hline Flagella & Single polar & Single polar or bipolar & Single polar & Polar & Bipolar \\
\hline \multicolumn{6}{|l|}{ Growth at/in: } \\
\hline $30{ }^{\circ} \mathrm{C}$ & - & - & + & - & + \\
\hline $6 \% \mathrm{NaCl}$ & - & - & + & + & + \\
\hline Catalase & + & $\mathrm{w}$ & + & + & + \\
\hline Gelatinase & - & + & - & - & + \\
\hline DNase & + & + & ND & - & - \\
\hline Lipase & + & + & - & ND & $\mathrm{ND}$ \\
\hline Nitrate reduction & + & + & $\mathrm{ND}$ & - & - \\
\hline \multicolumn{6}{|l|}{ Hydrolysis of: } \\
\hline Tween 40 & - & - & + & ND & ND \\
\hline Tween 80 & - & - & + & - & $\mathrm{ND}$ \\
\hline Acid production from sugars & + & + & + & + & - \\
\hline DNA G +C content (mol\%) & $46.6-47.0$ & 46.7 & 52.2 & 46.3 & $48-50$ \\
\hline
\end{tabular}


Table 2. Fatty acid contents of the two novel species of the genus Amphritea and the type species of related genera

Strains: 1, A. japonica sp. nov. JAMM $1866^{\mathrm{T}}$ (data from this study); 2 , A. balenae sp. nov. JAMM $1525^{\mathrm{T}}$ (data from this study); 3, A. atlantica $\mathrm{M}_{41}{ }^{\mathrm{T}} ; \quad 4$, Neptunomonas naphthovorans ATCC $700637^{\mathrm{T}}$; 5, Oceanospirillum linum NBRC $15448^{\mathrm{T}}$. tr, Trace $(<1 \%)$; empty cells indicate that the fatty acid was not detected. Data for taxa 3-5 are from Gärtner et al. (2008), Miyazaki et al. (2008a) and Sakane \& Yokota (1994).

\begin{tabular}{|lrrrrr|}
\hline Fatty acid & $\mathbf{1}$ & $\mathbf{2}$ & $\mathbf{3}$ & $\mathbf{4}$ & $\mathbf{5}$ \\
\hline Non-polar: & & & & & \\
$\mathrm{C}_{10: 0}$ & & & $\operatorname{tr}$ & & \\
$\mathrm{C}_{12: 0}$ & & & 2 & 7 & 3 \\
$\mathrm{C}_{12: 1}$ & 3 & 4 & & 4 & 2 \\
$\mathrm{C}_{14: 0}$ & & & & & 1 \\
$\mathrm{C}_{15: 1}$ & & & & & \\
$\mathrm{C}_{16: 0}$ & 18 & 14 & 29 & 21 & 16 \\
$\mathrm{C}_{16: 1}$ & 37 & 47 & 43 & 41 & 48 \\
$\mathrm{C}_{18: 0}$ & 1 & $\operatorname{tr}$ & $\operatorname{tr}$ & $\operatorname{tr}$ & \\
$\mathrm{C}_{18: 1}$ & 35 & 34 & 22 & 28 & 30 \\
$\mathrm{C}_{18: 2}$ & 5 & 2 & & & \\
$\mathrm{C}_{20: 1}$ & $\operatorname{tr}$ & & & & \\
$3-$ Hydroxy: $\dagger$ & & & & & \\
$\mathrm{C}_{10: 0}$ & 58 & 81 & 64 & 100 & 100 \\
$\mathrm{C}_{12: 1}$ & 42 & 19 & 36 & & \\
\hline
\end{tabular}

${ }^{\star}$ Numbers refer to the percentage of an acid relative to the total nonpolar fatty acids.

$\dagger$ Numbers refer to the percentage of an acid relative to the total hydroxy fatty acids.

(Stackebrandt \& Goebel, 1994; Stackebrandt et al., 2002). The generally recognized criteria for delineating bacterial species state that strains with a DNA-DNA relatedness of less than $70 \%$, as measured by hybridization, represent separate species (Wayne et al., 1987). The results of DNA-DNA hybridization analysis of the isolated strains and A. atlantica M $41^{\mathrm{T}}$ showed that there was greater than $91 \%$ DNA-DNA relatedness between strains JAMM $1866^{\mathrm{T}}$ and JAMM 1548, but the relatedness values between these two strains, JAMM $1525^{\mathrm{T}}$ and A. atlantica were less than $18 \%$ and each group was clearly separate, representing distinct species according to the recommendations of Wayne et al. (1987).

From the results of phenotypic, genotypic and phylogenetic analyses, it is evident that the three isolated strains represent two novel species within the genus Amphritea for which the names Amphritea japonica sp. nov. and Amphritea balenae sp. nov. are proposed.

\section{Description of Amphritea japonica sp. nov.}

Amphritea japonica (ja.po'ni.ca. N.L. fem. adj. japonica pertaining to Japan, where the isolate originated).

Cells are rod-shaped; cell width ranges from 0.6 to $0.9 \mu \mathrm{m}$ and cell length ranges from 0.9 to $1.7 \mu \mathrm{m}$ (see
Supplementary Fig. S1 in IJSEM Online). Cells are Gramnegative, non-spore-forming, chemo-organotrophic and motile by means of a single polar flagellum. Colonies on MA are circular with entire edges, smooth, convex, cream coloured and $0.5-1.0 \mathrm{~mm}$ in diameter after 1-2 days incubation at $20{ }^{\circ} \mathrm{C}$. The optimal growth temperature is $22-24{ }^{\circ} \mathrm{C}$. Growth occurs at 4 and $28{ }^{\circ} \mathrm{C}$, but not above $30{ }^{\circ} \mathrm{C}$. Optimal growth occurs in the presence of $3 \% \mathrm{NaCl}$. Growth occurs in the presence of $2 \%$ and $5 \% \mathrm{NaCl}$, but not without $\mathrm{NaCl}$ or in the presence of $>6 \% \mathrm{NaCl}$. Growth occurs at $\mathrm{pH} 6.5$ and $\mathrm{pH} 8.0$, but not at $\mathrm{pH} 6.0$ or at $\mathrm{pH}$ values greater than 8.5. Facultatively anaerobic and capable of respiratory metabolism. Catalase and cytochrome oxidase tests are positive. Does not produce $\mathrm{H}_{2} \mathrm{~S}$ or indole. Nitrate is reduced to nitrite, but nitrite is not reduced. DNase and lipase (tri- $n$-butyrin) are positive. Gelatinase, protease, amylase, urease and agarase are negative. Acid is formed oxidatively from glycerol. No acid is produced from L-arabinose, cellobiose, D-fructose, D-galactose, D-glucose, myo-inositol, D-lactose, maltose, Dmannitol, D-mannose, raffinose, L-rhamnose, D-sorbitol, sucrose, trehalose or xylose. Susceptible to ampicillin, chloramphenicol, erythromycin, gentamicin, nalidixic acid, neomycin, novobiocin and penicillin, but resistant to tetracycline. Variable susceptibility to kanamycin and streptomycin. Carbon sources oxidized (Biolog GN2) are methyl $\alpha$-D-glucoside, xylitol, acetic acid, $\alpha$-ketovaleric acid, lactamide, L-glutamic acid, glycyl-L-glutamic acid, methyl $\beta$-D-glucoside, stachyose, L-malic acid, methyl pyruvate, succinamic acid and L-alanine. The $\mathrm{G}+\mathrm{C}$ content of the DNA is about $46.6-47.0 \mathrm{~mol} \%$ (determined using HPLC). The major isoprenoid quinone is Q-8. The cellular fatty acids are $\mathrm{C}_{16: 1}, \mathrm{C}_{18: 1}, \mathrm{C}_{16: 0}, \mathrm{C}_{18: 2}, \mathrm{C}_{10: 0} 3$ $\mathrm{OH}, \mathrm{C}_{12: 1} 3-\mathrm{OH}, \mathrm{C}_{12: 1}, \mathrm{C}_{18: 0}$ and $\mathrm{C}_{18: 0}$; full details are given in Table 2.

The type strain, JAMM $1866^{\mathrm{T}}\left(=\mathrm{JCM} 14782^{\mathrm{T}}=\right.$ ATCC BAA- $1530^{\mathrm{T}}$ ), was isolated from sediment adjacent to a sperm whale carcass off Kagoshima, Japan. A second strain of this species, JAMM 1548, was also isolated from the same environment.

\section{Description of Amphritea balenae sp. nov.}

Amphritea balenae (ba.le' nae. L. gen. n. balenae of a whale).

Cells are rod-shaped; cell width ranges from 0.6 to $0.9 \mu \mathrm{m}$ and cell length ranges from 1.3 to $2.0 \mu \mathrm{m}$ (see Supplementary Fig. S1 in IJSEM Online). Cells are Gramnegative, non-spore-forming, chemo-organotrophic and motile by means of a single polar or bipolar flagellum. Colonies on MA are circular with entire edges, smooth, convex, cream coloured and $0.5-1.0 \mathrm{~mm}$ in diameter after 1-2 days incubation at $20{ }^{\circ} \mathrm{C}$. The optimal growth temperature is $20-22{ }^{\circ} \mathrm{C}$. Growth occurs at 4 and $28{ }^{\circ} \mathrm{C}$, but not above $30{ }^{\circ} \mathrm{C}$. Optimal growth occurs in the presence of $3 \% \mathrm{NaCl}$. Growth occurs in the presence of $2 \%$ and $3 \% \mathrm{NaCl}$, but not without $\mathrm{NaCl}$ or in the presence of $>4 \% \mathrm{NaCl}$. Growth occurs at $\mathrm{pH} 6.5$ and at $\mathrm{pH} 7.5$, but 
not at $\mathrm{pH} 6.0$ or at $\mathrm{pH}$ values greater than 8.0. Facultatively anaerobic and capable of respiratory metabolism. The catalase test is weakly positive and the cytochrome oxidase test is positive. Does not produce $\mathrm{H}_{2} \mathrm{~S}$ or indole. Nitrate is reduced to nitrite, but nitrite is not reduced. Gelatinase, DNase and lipase (tri- $n$-butyrin) are positive. Protease, amylase, urease and agarase are negative. Acid is formed oxidatively from glycerol. No acid is produced from Larabinose, cellobiose, D-fructose, D-galactose, D-glucose, myo-inositol, D-lactose, maltose, D-mannitol, D-mannose, raffinose, L-rhamnose, D-sorbitol, sucrose, trehalose or xylose. Susceptible to ampicillin, chloramphenicol, kanamycin, nalidixic acid, neomycin, novobiocin and penicillin, intermediately susceptible to erythromycin, gentamicin and streptomycin and resistant to tetracycline. Carbon sources oxidized (Biolog GN2) are $\beta$-hydroxybutyric acid, D-malic acid, L-asparagine, L-serine, fructose 6-phosphate, methyl $\beta$-D-glucoside, stachyose, L-malic acid, methyl pyruvate, succinamic acid and L-alanine. The major isoprenoid quinone is $\mathrm{Q}-8$. The cellular fatty acids are $\mathrm{C}_{16: 1}, \mathrm{C}_{18: 1}, \mathrm{C}_{16: 0}, \mathrm{C}_{10: 0} 3-\mathrm{OH}, \mathrm{C}_{12: 1}, \mathrm{C}_{18: 2}, \mathrm{C}_{12: 1} 3-\mathrm{OH}$ and $\mathrm{C}_{18: 0}$; full details are given in Table 2 .

The type strain, JAMM $1525^{\mathrm{T}}\left(=\mathrm{JCM} \quad 14781^{\mathrm{T}}=\right.$ ATCC BAA- $1529^{\mathrm{T}}$ ), was isolated from the sediment adjacent to a sperm whale carcass off Kagoshima, Japan. The DNA G + C content of the type strain is about $46.7 \mathrm{~mol} \%$ (determined using HPLC).

\section{Acknowledgements}

We would like to thank Mr Katsuyuki Uematsu and Ms Tomoko Takahashi for assistance in preparing electron micrographs. We are very grateful to the ROV Hyper Dolphin operation team and the crew of the R/V Natushima for helping us to collect the deep-sea samples.

\section{References}

Barrow, G. I. \& Feltham, R. K. A. (1993). Cowan and Steel's Manual for the Identification of Medical Bacteria, 3rd edn. Cambridge: Cambridge University Press.

Braby, C. E., Rouse, G. W., Johnson, S. B., Jones, W. J. \& Vrijenhoek, R. C. (2007). Bathymetric and temporal variation among Osedax boneworms and associated megafauna on whale-falls in Monterey Bay, California. Deep Sea Res Part I Oceanogr Res Pap 54, 1773-1791.

Ezaki, T., Hashimoto, Y. \& Yabuuchi, E. (1989). Fluorometric deoxyribonucleic acid-deoxyribonucleic acid hybridization in microdilution wells as an alternative to membrane filter hybridization in which radioisotopes are used to determine genetic relatedness among bacterial strains. Int J Syst Bacteriol 39, 224-229.

Felsenstein, J. (1981). Evolutionary trees from DNA sequences: a maximum likelihood approach. J Mol Evol 17, 368-376.

Fujikura, K., Fujiwara, Y. \& Kawato, M. (2006). A new species of Osedax (Annelida: Siboglinidae) associated with whale carcasses off Kyushu, Japan. Zoolog Sci 23, 733-740.

Fujiwara, Y., Kawato, M., Yamamoto, T., Yamanaka, T., Sato-Okoshi, W., Noda, C., Tuchida, S., Komai, T., Cubelio, S. S. \& other authors (2007). Three-year investigations into sperm whale-fall ecosystems in Japan. Mar Ecol 28, 219-232.
Garrity, G. M., Bell, J. A. \& Lilburn, T. (2005). Order VIII. Oceanospirillales ord. nov. In Bergey's Manual of Systematic Bacteriology, 2nd edn, vol. 2 (The Proteobacteria), part B (The Gammaproteobacteria), p. 270. Edited by D. J. Brenner, N. R. Krieg, J. T. Staley \& G. M. Garrity. New York: Springer.

Gärtner, A., Wiese, J. \& Imhoff, J. F. (2008). Amphritea atlantica gen. nov., sp. nov., a gammaproteobacterium from the Logatchev hydrothermal vent field. Int J Syst Evol Microbiol 58, 34-39.

Glover, A. G., Källström, B., Smith, C. R. \& Dahlgren, T. G. (2005). World-wide whale worms? A new species of Osedax from the shallow north Atlantic. Proc Biol Sci 272, 2587-2592.

Goffredi, S. K., Johnson, S. B. \& Vrijenhoek, R. C. (2007). Genetic diversity and potential function of microbial symbionts associated with newly discovered species of Osedax polychaete worms. Appl Environ Microbiol 73, 2314-2323.

Hedlund, B. P., Geiselbrecht, A. D., Bair, T. J. \& Staley, J. T. (1999). Polycyclic aromatic hydrocarbon degradation by a new marine bacterium, Neptunomonas naphthovorans gen. nov., sp. nov. Appl Environ Microbiol 65, 251-259.

Holt, J. G., Krieg, N. R., Sneath, P. H. A., Staley, J. T. \& Williams, S. T. (editors) (1994). Bergey's Manual of Determinative Bacteriology, 9th edn. Baltimore: Williams \& Wilkins.

Hugh, R. \& Leifson, E. (1953). The taxonomic significance of fermentative versus oxidative metabolism of carbohydrates by various Gram negative bacteria. J Bacteriol 66, 24-26.

Komagata, K. \& Suzuki, K. (1987). Lipid and cell-wall analysis in bacterial systematics. Methods Microbiol 19, 161-207.

Krieg, N. R. (1984). Aerobic/microaerophilic, motile, helical/vibrioid Gram-negative bacteria. In Bergey's Manual of Systematic Bacteriology, vol. 1, pp. 104-110. Edited by N. R. Krieg \& J. G. Holt. Baltimore: Williams \& Wilkins.

Ludwig, W., Strunk, O., Westram, R., Richter, L., Meier, H., Yadhukumar, Buchner, A., Lai, T., Steppi, S. \& other authors (2004). ARB: a software environment for sequence data. Nucleic Acids Res 32, 1363-1371.

Miyazaki, M., Nogi, Y., Usami, R. \& Horikoshi, K. (2006). Shewanella surugensis sp. nov., Shewanella kaireitica sp. nov. and Shewanella abyssi sp. nov., isolated from deep-sea sediments of Suruga Bay, Japan. Int J Syst Evol Microbiol 56, 1607-1613.

Miyazaki, M., Nogi, Y., Fujiwara, Y., Kawato, M., Kubokawa, K. \& Horikoshi, K. (2008a). Neptunomonas japonica sp. nov., an Osedax japonicus symbiont-like bacterium isolated from sediment adjacent to sperm whale carcasses off Kagoshima, Japan. Int J Syst Evol Microbiol 58, 866-871.

Miyazaki, M., Nogi, Y., Ohta, Y., Hatada, Y., Fujiwara, Y., Ito, S. \& Horikoshi, K. (2008b). Microbulbifer agarilyticus sp. nov. and Microbulbifer thermotolerans sp. nov., agar-degrading bacteria isolated from deep-sea sediment. Int J Syst Evol Microbiol 58, 1128-1163.

Nogi, Y., Kato, C. \& Horikoshi, K. (1998). Taxonomic studies of deepsea barophilic Shewanella strains and description of Shewanella violacea sp. nov. Arch Microbiol 170, 331-338.

Rouse, G. W., Goffredi, S. K. \& Vrijenhoek, R. C. (2004). Osedax: bone-eating marine worms with dwarf males. Science 305, 668-671.

Saito, H. \& Miura, K. I. (1963). Preparation of transforming deoxyribonucleic acid by phenol treatment. Biochim Biophys Acta 72, 619-629.

Saitou, N. \& Nei, M. (1987). The neighbor-joining method: a new method for reconstructing phylogenetic trees. Mol Biol Evol 4, 406425.

Sakane, T. \& Yokota, A. (1994). Chemotaxonomic investigation of heterotrophic, aerobic and microaerophilic spirilla, the genera 
Aquaspirillum, Magnetospirillum, and Oceanospirillum. Syst Appl Microbiol 17, 128-134.

Satomi, M., Kimura, B., Hamada, T., Harayama, S. \& Fujii, T. (2002). Phylogenetic study of the genus Oceanospirillum based on 16S rRNA and gyrB genes: emended description of the genus Oceanospirillum, description of Pseudospirillum gen. nov., Oceanobacter gen. nov. and Terasakiella gen. nov. and transfer of Oceanospirillum jannaschii and Pseudomonas stanieri to Marinobacterium as Marinobacterium jannaschii comb. nov. and Marinobacterium stanieri comb. nov. Int J Syst Evol Microbiol 52, 739-747.

Stackebrandt, E. \& Goebel, B. M. (1994). Taxonomic note: a place for DNA-DNA reassociation and $16 \mathrm{~S}$ rRNA sequence analysis in the present species definition in bacteriology. Int J Syst Bacteriol 44, 846-849.

Stackebrandt, E., Frederiksen, W., Garrity, G. M., Grimont, P. A. D., Kämpfer, P., Maiden, M. C. J., Nesme, X., Rosselló-Mora, R.,
Swings, J. \& other authors (2002). Report of the ad hoc committee for the re-evaluation of the species definition in bacteriology. Int $J$ Syst Evol Microbiol 52, 1043-1047.

Swofford, D. L. (1998). PAUP ${ }^{*}$ 4.0: Phylogenetic analysis using parsimony (and other methods). Sunderland, MA: Sinauer Associates.

Tamaoka, J. \& Komagata, K. (1984). Determination of DNA base composition by reversed-phase high-performance liquid chromatography. FEMS Microbiol Lett 25, 125-128.

Wayne, L. G., Brenner, D. J., Colwell, R. R., Grimont, P. A. D., Kandler, O., Krichevsky, M. I., Moore, L. H., Moore, W. E. C., Murray, R. G. E. \& other authors (1987). International Committee on Systematic Bacteriology. Report of the ad hoc committee on reconciliation of approaches to bacterial systematics. Int $J$ Syst Bacteriol 37, 463-464. 